\title{
AN ANALYSIS OF THE MICROSTRUCTURE, MACROSTRUCTURE AND MICROHARDNESS OF NiCr-Ir JOINTS PRODUCED BY LASER WELDING WITH AND WITHOUT PREHEAT
}

\begin{abstract}
This paper discusses some of the basic problems involved in laser welding of dissimilar materials with significant differences in melting points. It focuses on the micro and macrostructure of laser welded NiCr-Ir microjoints used in central spark plug electrodes. The joints were produced by welding with and without preheat using an Nd,YAG laser. The structure and composition of the welded joints were analyzed by means of a light microscope (LM) and a scanning electron microscope (SEM) equipped with an energy dispersive X-ray (EDX) spectrometer. The microhardness of the weld area was also studied.

Keywords: microstructure, microhardness, microjoint, laser welding, refractory metals
\end{abstract}

\section{Introduction}

With the general trend toward miniaturization of everyday objects, it has become increasingly common to produce welding joints between very small parts. High precision can be achieved using, for example, laser beam welding. Compared with conventional welding, this method produces a smaller heat-affected zone because the energy of light converted into heat does not cause excessive melting of the surfaces being joined. The concentration of laser radiation energy is dependent on the spot size (distance from the focus) and the pulse duration (both for single and repeated pulses). Since a high-intensity radiation source is used, no electric current flows through the workpiece, as is the case of conventional welding processes. As a result, no electrical or polarization effects are observed in the weld area [1-6].

In laser beam welding, when radiation strikes the workpiece surface, most energy is reflected; only some is absorbed and, because of heat conductivity, transferred deep into the material. The degree of absorption is dependent on the laser wavelength and the physical properties and surface finish of the materials joined $[1,3,5-8]$.

The higher the temperature of the heated material at the surface, the higher the absorption of the radiation. For metals laser processed in ambient air, higher absorption occurs also as a result of the surface oxidation; oxides usually absorb radiation better than metals. A further, very rapid, increase in absorption leads to a change in the state of matter, from solid to liquid (melting) [8].
The efficiency of the laser heating process can be improved by increasing the absorptivity of the metal surfaces. This is achieved by $[1,3]$,

- roughening (e.g. sand blasting, shot peening, knurling, and roughening with sand paper), which can increase the absorptivity up to $30-40 \%$;

- $\quad$ oxidation, which can increase the absorptivity up to $30-40 \%$, and rarely up to $70 \%$;

- $\quad$ raising the surface temperature (preheating of the pieces to be laser welded using an arbitrary method), which can increase the absorptivity up to $10-30 \%$;

- deposition of an absorptive and, in most cases, antireflective film, a painted coating (a paint, varnish or suspension layer), a powder coating, a paste coating, a galvanic coating, a chemical coating and other coatings that absorb radiation well.

Modern welding technologies are still insufficient to produce perfect joints, i.e. joints without flaws $[1,3]$.

Weld discontinuities observed in microwelding are identical to those occurring in conventional welding. The main difference lies in the small size and low thermal capacity of parts to be welded; they are responsible for an escalation in weld discontinuities due to overheating [9-11].

A weld discontinuity is an imperfection of a weld which may negatively affect the quality (structure and/or shape) and service life of a whole product. A weld discontinuity can be permissible when its dimension does not exceed the maximum dimension specified by an appropriate standard or regulation [11-13].

\footnotetext{
KIELCE UNIVERSITY OF TECHNOLOGY, DEPARTMENT OF INDUSTRIAL ELECTRICAL ENGINEERING AND AUTOMATIC CONTROL, DIVISION OF POWER ELECTRONICS AND ELECTRICAL MACHINES AND DRIVES, FACULTY OF ELECTRICAL ENGINEERING, AUTOMATIC CONTROL AND COMPUTER SCIENCE, $7^{\text {th }}$ TYSIACCLECIA P.P. AV. 25-314 KIELCE, POLAND

* KIELCE UNIVERSITY OF TECHNOLOGY, LASER PROCESSING RESEARCH CENTRE, DIVISION OF SURFACE ENGINEERING, FACULTY OF MECHATRONICS AND MECHANICAL ENGINEERING, $7^{\text {th }}$ TYSIACCLECIA P.P. AV. 25-314 KIELCE, POLAND

*** UNIVERSITY OF ŽILINA, FACULTY OF MECHANICAL ENGINEERING, DEPARTMENT OF TECHNOLOGICAL ENGINEERING, 8215/1 UNIVERZITNÁ STR., 010 26 ŽILINA, SLOVAKIA 
Selecting the laser beam parameters is a complex process, which requires expertise not only in laser equipment but also materials engineering. One of the advantages of laser welding is that it can eliminate or reduce weld defects found after conventional welding which result from the considerable difference in the melting point between the materials joined. The current projects at the Laser Processing Research Centre of the Kielce University of Technology include laser microwelding of iridium (solid wire) to nickel chromium alloy (base metal) [14-15].

\section{Methodology}

The investigations were conducted for fillet NiCr-Ir joints produced by laser microwelding. They included an analysis of their micro- and macrostructure and measurement of changes in microhardness in the characteristic zones. Microwelding was performed using a Rofin laser system, which comprises an $\mathrm{Nd}$,YAG laser operating in a pulsed or continuous mode able to generate a beam with a wavelength of $1064 \mathrm{~nm}$ and a spot size of $0.4 \mathrm{~mm}$. The system includes an automated workbench with five degrees of freedom. The maximum laser power is $12 \mathrm{~kW}$, and the pulse duration ranges from 0.3 to $50 \mathrm{~ms}$.

The joints were produced using single partly overlapping pulses along the contact line between an iridium wire $0.8 \mathrm{~mm}$ in diameter and an $\mathrm{NiCr}$ alloy base metal. The precision of the microwelding process was increased by using resistance welding to initially join the materials. The pieces to be welded were placed in a specially developed and constructed clamp to avoid displacements caused by blows of a shielding gas. The shielding gas in the microwelding process was argon.

Two cases of welding were considered. In case one (variant A), the pieces were welded at a room temperature - without preheating. The other case (variant B) involved preheating the parts to a temperature of $750^{\circ} \mathrm{C}$, and then keeping that temperature while performing laser welding at the same parameters as in case one. After the welding was completed, the parts were left to cool slowly. The preheating was carried out by means of another specially developed and constructed device.
The joints were produced at different laser welding parameters. In both cases, the macroscopic observations of the joints were conducted first visually and then with a Hirox KH-8700 digital microscope (Fig. 1), with magnification ranging from 35 to $5000 \times$. The aim of the preliminary microscopic analysis was to select welds with a correctly produced seam containing no outside cracks. The selected specimens were used to prepare metallographic sections for microstructural observations with two scanning electron microscopes, a JEOL JSM 5400 (Fig. 5) and a JEOL JSM 7100F (Fig. 2).

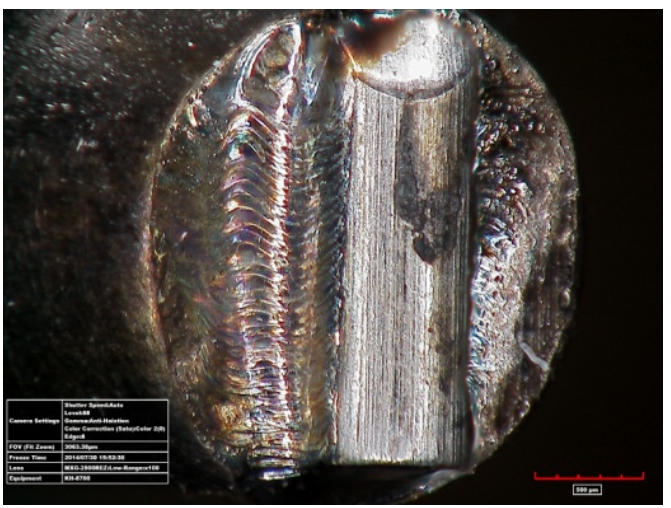

Fig. 1. A macroscopic view of the materials joined

The micro- and macroscopic analysis was followed by microhardness measurement performed by means of an INNOVATEST Nexus 4303 tester in accordance with a standard procedure. The results were represented graphically. Microhardness was measured in the base metal ( $\mathrm{NiCr}$ ), in the fusion zone, and below the fusion line where iridium penetrated into $\mathrm{NiCr}$, with that being a consequence of the preheating of the parts to be welded.

\section{Results and discussion}

The images below show results obtained for welds between a nickel-chromium alloy part and a solid iridium wire produced by laser microwelding with and without preheating.

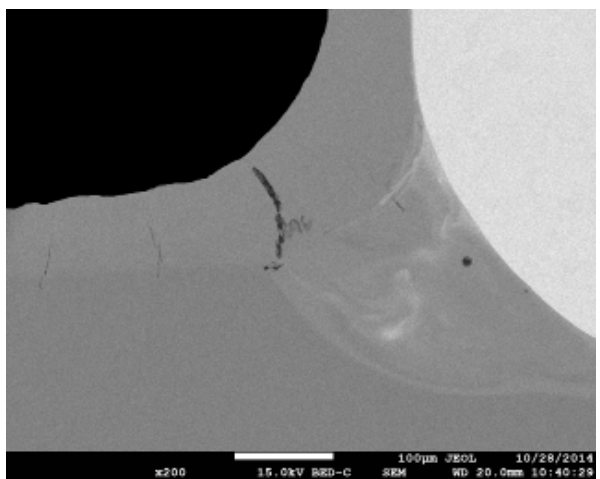

a)

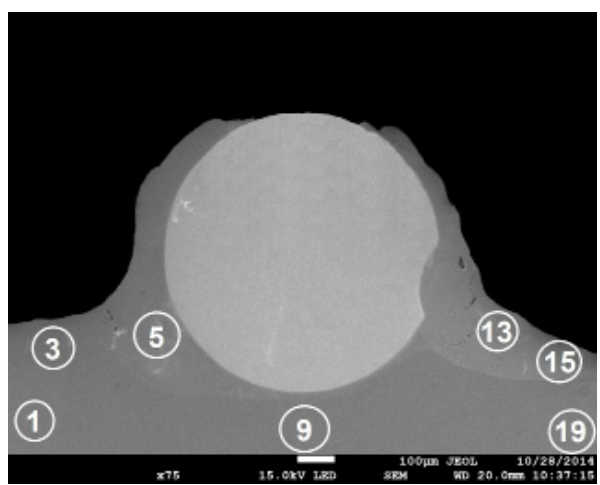

b)

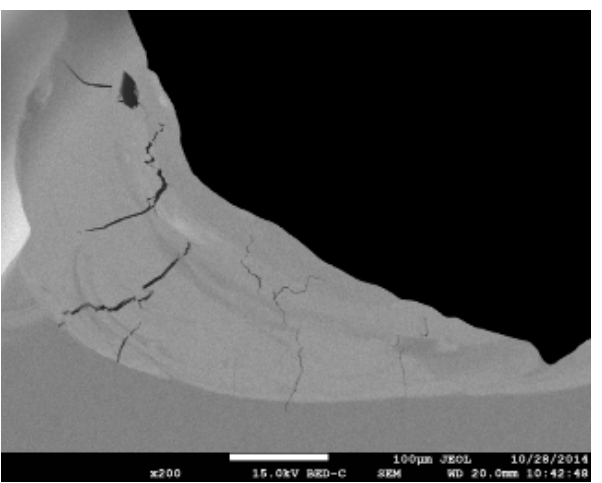

c)

Fig. 2. Views of variant A joints, a) and c) left and right sides, respectively (magnification $200 \times$ ) b) microhardness measurement points (magnification $75 \times)$ 


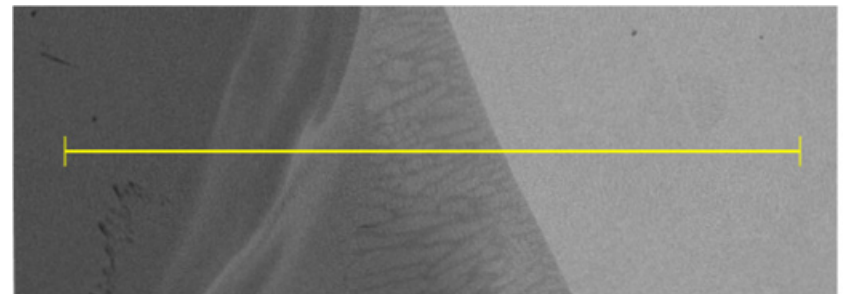

Ni Ka1

气̆
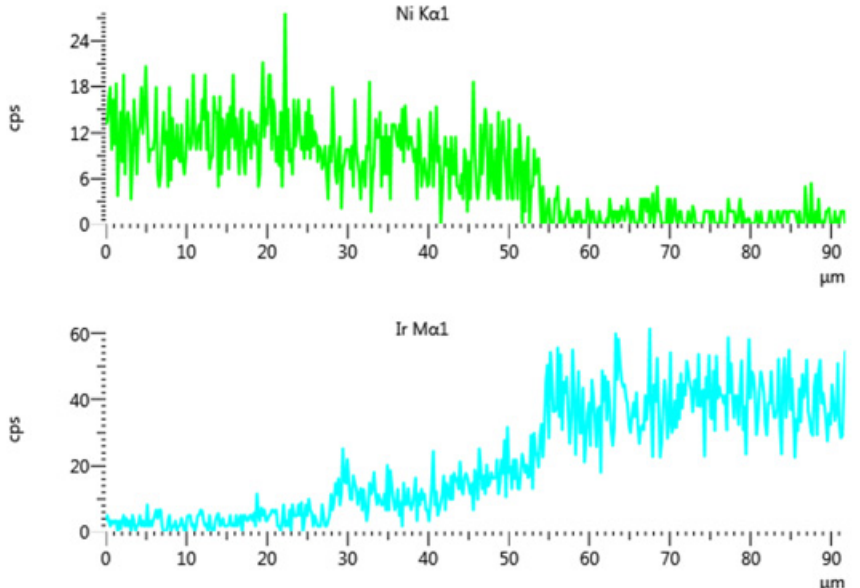
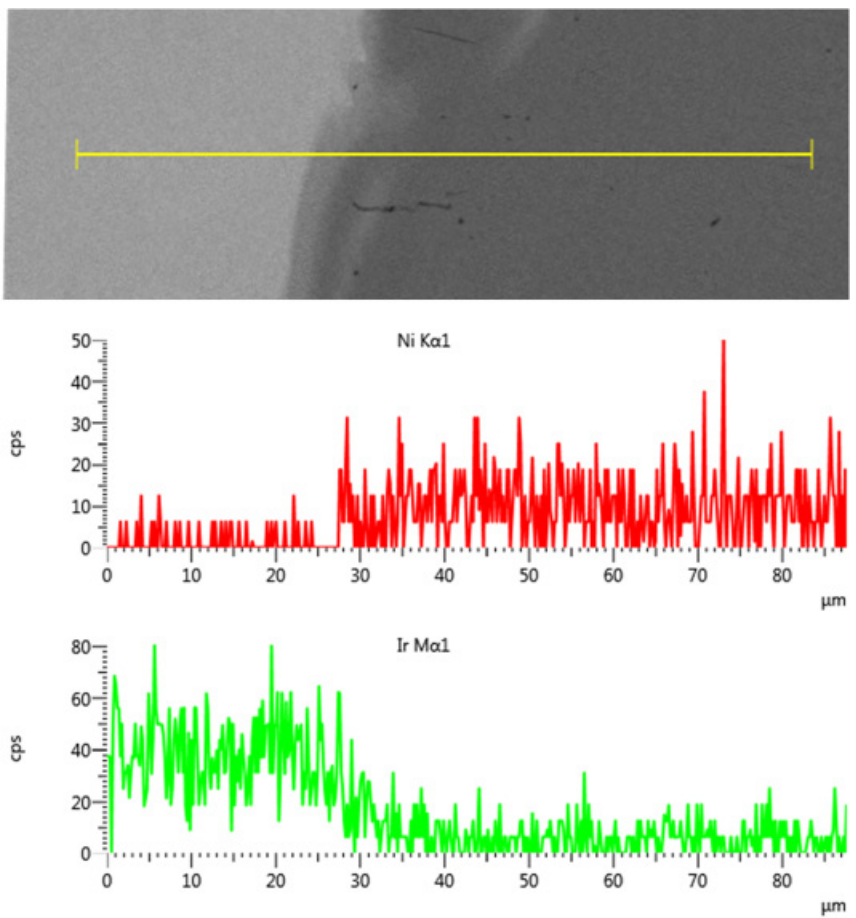

Fig. 3. Distribution of selected elements in variant A joints, according to (Figs. 2a,c)

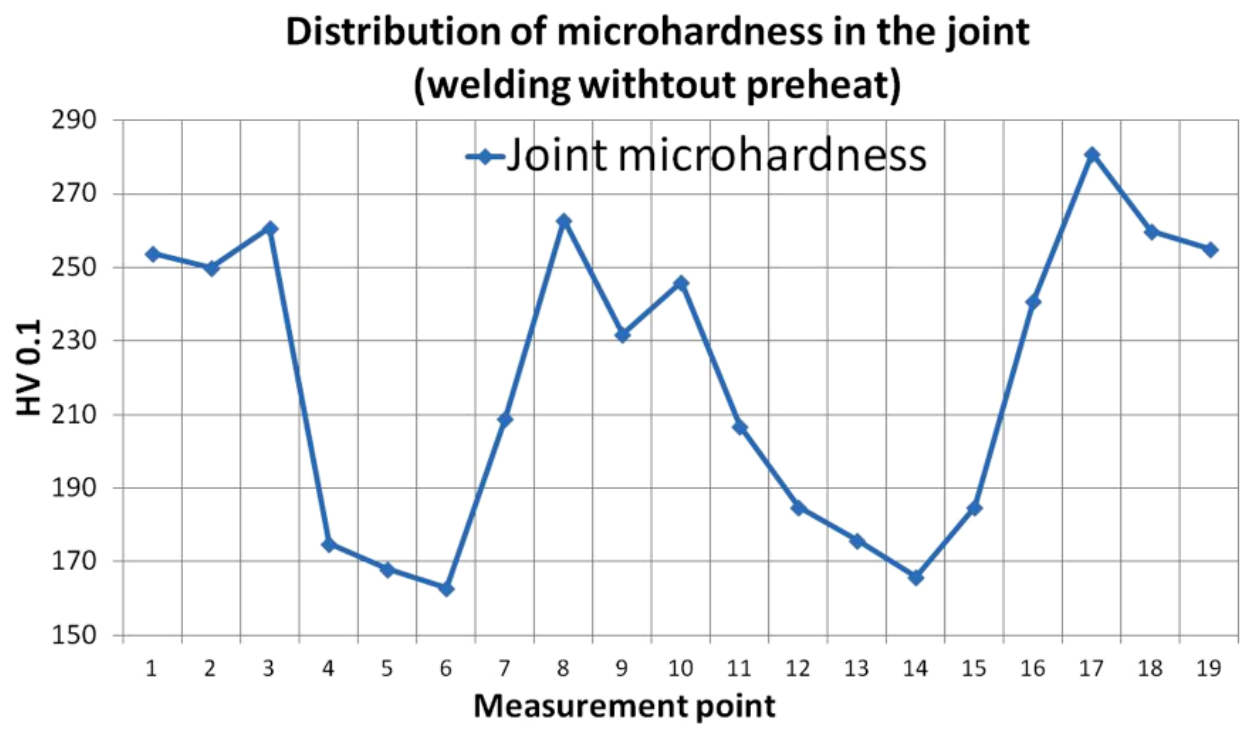

Fig. 4. Distribution of microhardness of a variant A joint, according to Fig. $2 b$

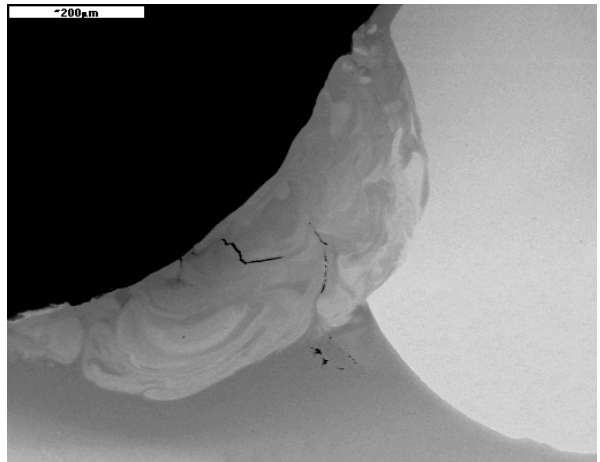

a)

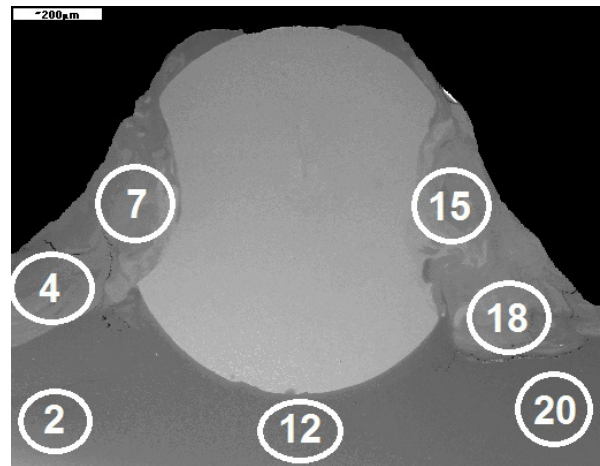

b)

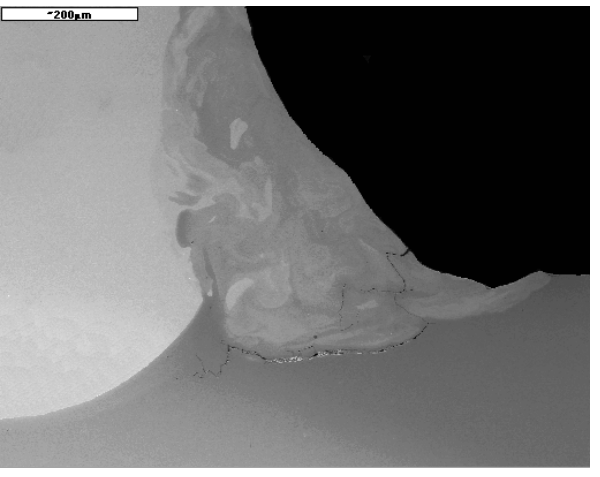

c)

Fig. 5. Views of variant B joints, a) and c) left and right sides, respectively (magnification $200 \times$ ), b) microhardness measurement points (magnification $75 \times$ ) 

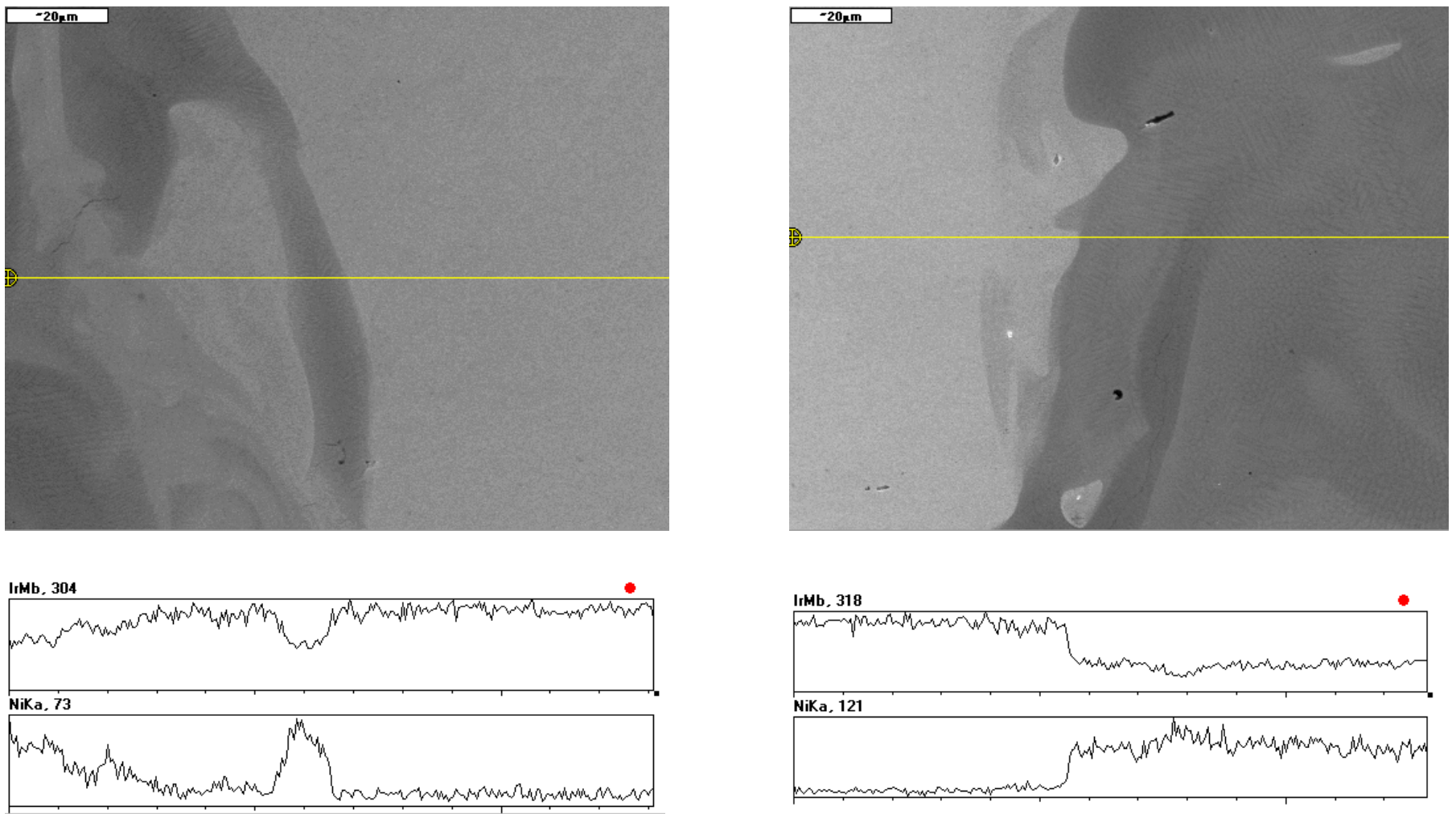

Fig. 6. Distribution of selected elements in variant B joints, according to (Figs. 5a,c)

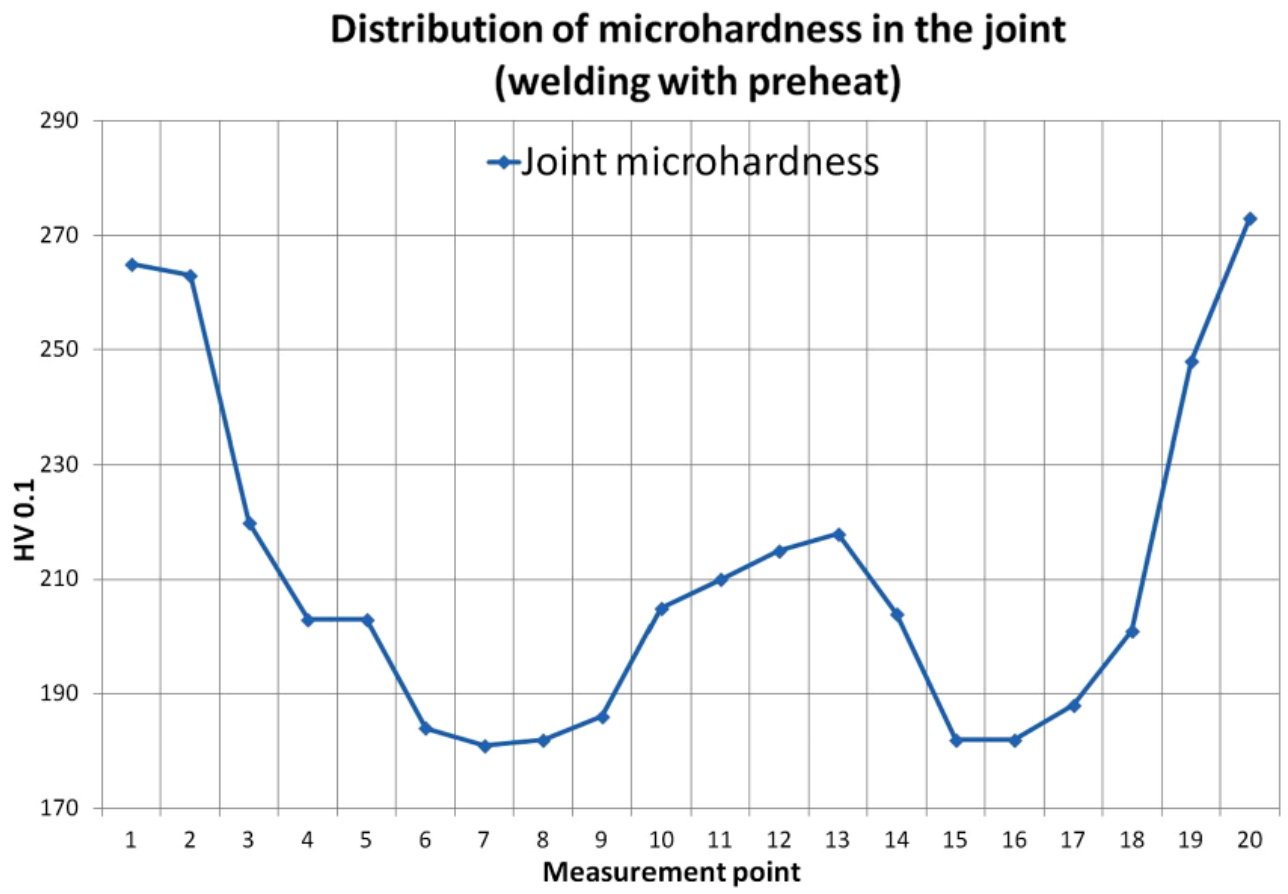

Fig. 7. Distribution of microhardness in a variant B joint, according to Fig. $5 \mathrm{~b}$

Figure 1 shows a macroimage of a welding joint between a solid iridium wire $0.8 \mathrm{~mm}$ in diameter and a nickel-chromium alloy base metal. The photograph was taken using a HIROX KH-8700 digital microscope. While the weld was produced, there were continuous displacements of the material, which caused considerable overlapping of laser pulses. As a result, the solidification traces formed a uniform sequence of arcs.
Figures 2 and 5 show metallographic sections of the weld area for variant A and variant B, respectively. As can be seen, the mixing of the materials was different for the two welding cases. In Fig. 5, the mixing was significant. Weld pool convection, which occurred during welding, was responsible for different degrees of mixing of $\mathrm{NiCr}$ with $\mathrm{Ir}$ (effect of material contrast in SEM images). The lighter color indicates places 
richer in iridium. In variant $\mathrm{A}$, the mixing of the materials was less uniform; there were small gas voids and microcracks, with the latter being higher in number than those found in variant $B$. Although microcracks (Figs. 2a, 2c, 5a) are most likely to occur in the weld area, they may propagate into the base metal (5c) and sometimes they can be found also in iridium. Weld discontinuities can have a negative effect on the serviceability of materials joined. Depending on the service conditions, they may contribute to higher thermal resistance or propagation of microcracks and consequently a failure of the joint.

Unfortunately, the presence of microcracks suggests that the time during which the materials were in liquid state was probably insufficient to obtain their uniform mixing and to induce compressive residual stresses. Preheating and then slow cooling helped reduce stress; however, it was impossible to completely eliminate the occurrence of stresses in the weld area.

Microhardness measurement results confirm that the values in the fusion zone were higher when a weld was produced with preheating. The microhardness of the base metal $(\mathrm{NiCr})$ and the iridium wire registered after welding without preheating were similar to those obtained after welding with preheat.

As can be seen from Figs. $2 b$ and 5b, no fusion occurred in the central region of the NiCr-Ir joints. The welded joints had a very narrow diffusion zone. The fusion zones shown in Figs. $2 \mathrm{a}, 2 \mathrm{c}, 5 \mathrm{a}$, and $5 \mathrm{c}$ differed, depending on the place where the laser beam impacted the material. The fusion zone was greater when the laser beam uniformly heated the base metal and the iridium wire. When the beam impacted the iridium wire mainly, iridium melted significantly over the surface of the base metal. On the other hand, when the laser beam hits the surface of the base metal mainly, the material vaporized. In both cases of incorrect fusion, there was no or insufficient mixing of the materials, which caused the occurrence of weld discontinuities.

It can thus be concluded that preheating contributed to better absorption of the laser beam and faster melting of the iridium wire. The melting point of iridium is $2447^{\circ} \mathrm{C}$, which is nearly $1000^{\circ} \mathrm{C}$ higher than the melting point of nickel. When iridium reaches its melting point, nickel is close to its boiling point, which is $2913^{\circ} \mathrm{C}$; this may lead to its vaporization and, consequently, a reduction in its content in the weld area. The large differences in the melting point between the two materials make it difficult to appropriately select the laser parameters and obtain a correct weld. The temperature of the weld pool was not measured during the welding operation. With these results, it would have been possible to assess with greater precision what influence the preheating had on the mixing of the materials and the production of defect-free welds.

\section{Conclusions}

The following conclusions were formulated on the basis of the experimental results obtained for pulsed laser microwelding with and without preheating.

- In the fusion zone, the mixing of iridium, which is a dif- ficult-to-melt material, and the NiCr alloy, whose melting point is much lower, was not uniform.

- Fusion was achieved at different parameters of pulsed laser welding, which, in the case of conventional welding, is difficult because the heating of the area to be fused lasts longer and causes the $\mathrm{NiCr}$ alloy to vaporize.

- The size of the melted area, which constitutes the weld, is mainly dependent on the duration of a single laser pulse.

- Welds produced with single laser pulses contain microcracks, irrespective of the process parameters; however, if preheating is applied, their number is smaller than that observed after welding without preheating.

- Preheating of materials to be welded contributes to higher microhardness in the fusion zone.

\section{Acknowledgments}

The research reported herein was supported by a grant from the National Centre for Research and Development (No. PBS1/B5/13/2012).

\section{REFERENCES}

[1] A. Klimpel, Spawanie zgrzewanie i cięcie metali, WNT, Warszawa, 1999.

[2] P.M Powel, Laser-Based Micromachining Gets Practical. Photonics Spectra, 70 (2003).

[3] R. Domański, Promieniowanie laserowe - oddziaływanie na ciała stałe. WNT, Warszawa, 1990.

[4] J. Pilarczyk, Poradnik inżyniera - Spawalnictwo Tom 1. Warszawa WNT 2003.

[5] N. Radek, R. Ślusarczyk, Wpływ parametrów spawania laserowego na własności mechaniczne spoiny. Przegląd Spawalnictwa 4, 18-20 (2002).

[6] N. Radek, B. Antoszewski, Influence of laser treatment on the properties of electro-spark deposited coatings. Kovove Materialy-Metallic Materials 47, 1, 31-38 (2009).

[7] N. Radek, Determining the operational properties of steel beaters after electrospark deposition. Eksploatacja i Niezawodność - Maintenance and Reliability 4, 10-16, (2009).

[8] N. Radek, K. Bartkowiak, Performance properties of electro-spark deposited carbide-ceramic coatings modified by laser beam. Physics Procedia (Elsevier) 5, 417-423 (2010).

[9] W. Danilczyk, St. Kruczyński, M. Stępniewski, R. Wołoszyn, Ocena połączeń Pt-NiCr na elektrodach świecy zapłonowej. VII Międzynarodowa Konferencja Naukowo-Techniczna „Logistyka, systemy transportowe, bezpieczeństwo w transporcie" - LOGITRANS 2010, Szczyrk.

[10] A. Zawadzki, S. Różowicz, Application of input - state of the system transformation for linearization of some nonlinear generators, International Journal of Control, Automation and Systems (2015) 13(3):1-8 ; DOI 10.1007/s12555-014-0026-3.

[11] H.T. Lin, M.P. Brady, R.K. Richards, D.M. Layton, Characterization of erosion and failure processes of spark plugs after filed 
1162

service in natural gas engines. Wydawnictwo WEAR (1063-1067) 2005.

[12] S. Javan, S.V. Hosseini, S.Sh. Alaviyoun, An experimental investigation of spark plug temperature in bi-fuel engine and its effect on electrode erosion. International Journal of Automotive Engineering 2, 1, (2012).

[13] G.W. Shoobert, Iridium electrodes increase spark plug life. Platinum Metals Rev. 1962.
[14] Sz. Tofil, B. Antoszewski, Problemy mikrospawania laserowego elementów z Ni-Cr, W oraz stopów Pt. Warstwa Wierzchnia Technologicznie Kształtowana Gorzów Wlkp. 2011.

[15] B. Grabas, Sz. Tofil, Mikrospawanie laserowe nakładek irydowych na elektrodę rdzeniową świecy zapłonowej - Sympozjum Katedr i Zakładów Spawalnictwa „Nowoczesne zastosowania technologii spawalniczych”, Brenna 17-18 czerwca 2014. 